COMPETITOR: Jurnal Pendidikan Kepelatihan Olahraga

Volume 13 Number 1 Year 2021

e-ISSN: 2657-0734 \& p-ISSN: 2085-5389

This work is licensed under a Creative Commons Attribution 4.0 International License

\title{
The Sp3or's Policy Evaluation in SDP Perspective: New Direction For Sports Development in The Future
}

\author{
Destri Hardiyani ${ }^{{ }^{*}}$,Yudha Munajat Saputra ${ }^{2}$, Amung Ma'mun ${ }^{3}$ \\ ${ }^{1,2,3}$ Postgraduate Program/Indonesian Education University/West Java/Indonesia \\ 1,2,3 J1. Dr. Setiabudhi No.229, Isola, Kec. Sukasari, Bandung City, West Java, 40154 \\ 1.
}

Received: December 21, 2020; Reviewed: January 25, 2021; Accepted: February 08, 2021; Published: February 28, 2021

\begin{abstract}
The purpose of this study was to determine the SP3OR's policy in the perspective of sport development and peace (SDP) for new directions of sports development in the future. Qualitative research was conducted, where semi-structured interview data were collected from participants, as were data from direct participant observations and organizational documents. Data analysis followed, according to triangulation. The results of this study indicate that the SP3OR's program through its tasks or activities to the community has received a very positive response, an increase in the number of community participation in sports in West Java Province tends to increase every year. So that the SP3OR's program is contained in the policy of Governor Regulation (Pergub) No. 7 of 2018 so that the consistency of programs running in the community is maintained. Thus the SP3OR's Program in West Java is expected to become an example for other provinces in Indonesia so that they can utilize human resources, especially youth, to build a human development index through sports activities.
\end{abstract}

Keywords: SP3OR's Policy Evaluation; Sport Development and Peace (SDP).

\section{INTRODUCTION}

Policy is the most important leadership product because it will be a means to achieve the goals outlined. Through superior policies, will provide opportunities for leaders to achieve success in leading (Ma'mun, 2015). Government policy in sports development is one of the pillars for maintaining health and fitness that can support the productivity of human resources (Rahadian, 2020). This sports development policy, among others, began in 1978 at its conference in Paris, UNESCO believes that one of the important conditions for fulfilling human rights effectively is that each individual must be free to develop and preserve physical health, intellectual and moral strength, as well as their access. to physical education and sports must be guaranteed. This then became one of the goals of the policy created by UNESCO that every human being is free to do physical activity and sports known as Sport for All. 
The Sp3or's Policy Evaluation In Sports For Development And Peace (SDP) Perspective: New Direction For Sports

Development In The Future

Destri Hardiyani, Yudha Munajat Saputra, Amung Ma'mun

destrihard@gmail.com

Simultaneously with the launch of the UNESCO's sport for all movement in 1978, Indonesia carried out an important sports development movement by launching a national program to socialize sports activities and foster wider interaction in the community. In 1983, through the movement "memasyarakatkan olahraga dan mengolahragakan masyarakat".

The government is very aware of the strategic role of sports so that it places sports development as a very important part of the human resource development agenda (Rahadian, 2020). West Java Province as the province with the largest population in Indonesia has a mission to increase the role of youth in development, community sports and sports achievements. The West Java mission is in line with the framework for the formation of Sport for Development and peace. Dispora (Dinas Pemuda dan Olahraga) as an actor in sports plays an important role in realizing one of the missions of West Java, and one of the many programs initiated by the Dispora is SP3OR. SP3OR is a scholar who is here to encourage, motivate and build people to exercise, and uphold peace so that the people of West Java can achieve better conditions in the health sector through sports.

Realizing that there are so many opportunities for SP3OR staff in carrying out their programs, it must be realized that the implemented program requires an assessment or evaluation, because according to Huffman (2011) that the most common criticism directed at the SDP sector is the weakness of literature sources containing measurement and evaluation. A clear program, which supports the effectiveness of sports in the development process.

\section{METHOD}

In this study, researchers will use qualitative research to examine the role and contribution of SP3OR's efforts in the SDP perspective for the future direction of sport development. Participants in qualitative research are better known as "informants", because the results of qualitative research are to get in-depth information on the selected research problem (Heryana, 2018). Heryana (2018) explains that in qualitative research, informants are divided into three, namely key informants, main informants and supporting informants. According to him, the use of the three types of informants above is for the purpose of data validity using the triangulation method, and the data processing stage in this qualitative research will go through the stages of data collection, reduction, 
The Sp3or's Policy Evaluation In Sports For Development And Peace (SDP) Perspective: New Direction For Sports

Development In The Future

Destri Hardiyani, Yudha Munajat Saputra, Amung Ma'mun

destrihard@gmail.com

data presentation and drawing conclusions.

\section{RESULTS AND DISCUSSION}

Starting with a key informant statement (YMS), he said that "So far, it is indicated that the results of the data we have done before this SP3OR take place only under $30 \%$ of the participation rate of the people of West Java to exercise." This is recorded clearly through the data held by Dispora Jawabarat (2020), it was explained that "Based on monitoring from SP3OR staff, initial data on community participation figures were recorded amounted to $22.68 \%$."

On the other hand, the demands of the community to carry out work are sufficient their living needs also continue to increase so that their working time will be longer and causing a reduction in free time owned by the community, consequently. There will also be fewer people who are interested in sports. According to Dispora of West Java (2020) the problem of sports participation usually originates as well the lack of intensive encouragement and invitation for people to exercise. With thus, the explanation above is the idea of the formation of the SP3OR program. About this SP3OR recruitment system has been explained directly by key informants and supporters that in the recruitment process, the Dispora of West Java through Dispora from each district has determined several criteria that must be met, including applicants must be graduates majoring in sports or bachelor of sports, and age restrictions not more than 40 years old and not yet bound by a work contract, as for more details regarding the process is for applicants who can participate in the selection, namely those who have received a recommendation from the respective District of Dispora and carry out the selection stage in the form of several test like Academic, Psychology, Skills and medical.

The selected SP3OR then took part in a training to increase knowledge as well SP3OR personnel skills. In 2020, namely batch IV has implemented training (character building) in Pangandaran Province for 3 consecutive days. The implementation of the training still observes the health protocol with the implement of $3 \mathrm{M}$ and must bring the results of a rapid test before entering the training area. This character building has a concept on knowledge, skills and attitude to equip the SP3OR personnel when directly involved in the community. Because after being elected, SP3OR will become a motor of sports participation in society with input performance indicators, process, and measurable output, applying a creative, innovative mindset, effective and efficient in designing and implementing sports culture programs in society; to become a pioneer in 
The Sp3or's Policy Evaluation In Sports For Development And Peace (SDP) Perspective: New Direction For Sports

Development In The Future

Destri Hardiyani, Yudha Munajat Saputra, Amung Ma'mun

destrihard@gmail.com

improving the human resources that drive sports in society, become a facilitator and impetus for the improvement of sports activity facilities in the community.

Having the opportunity to continue to develop, the SP3OR's Policy Direction was confirmed in the governor regulation number 7 of 2018. All policies regarding SP3OR are contained in it. The key informant (YMS) directly conveyed the background that "In order for this SP3OR to continue every year, because if it has become a governorate, it is the obligation of the provincial government to hold SP3OR every year." In addition, through a policy that has a clear legally, it is also clear that everything that is contained in it, such as the main duties and functions that must be performed by SP3OR, the contract system and even the payroll system.

Sequence Activities for Policy Implementation are initiated from the vision, mission, strategy/plan, policies, programs, projects and activities (Ma'mun, 2015). Rencana Pembangunan Jangka Panjang Daerah (RPJPD) is a development planning document for West Java Province for a period of 20 (twenty) years from 2005 until 2025, which contains the vision, mission, policy direction and main targets of long-term regional development length of West Java Province. The West Java RPJPD has a desired vision manifested namely "Dengan Iman dan Takwa, Provinsi Jawa Barat termaju di Indonesia" (RPJPD Jawa Barat, 2010).

Has the status of the province with the largest population in Indonesia, West Java Province has great potential for development areas, it can be seen from the human development index (IPM) in West Java which continues to experience an accelerated increase and increase IPM is focused on improving basic services, both education and health (Bappeda, 2020). Regarding the human development index, it is in line with one of the West Java missions in the "Rencana Pembangunan Jangka Menengah Daerah" (RPJMD) is "for give birth to cultured, quality, happy and productive human beings through improvement innovative public services, West Java aims to increase happiness and welfare of society with the target: increasing the role of youth in development, community sports and West Java sports achievements at the national level" (RPJMD, 2018). Judging from several of these objectives in line with the statement of (Ramadhan, 2020) that "the development of West Java can be supported by its relationship with one aspect, namely the sports aspect. If a look at the field of sport can help in its aim to optimize community participation, especially in terms of exercise to maintain his health and achieve a state of complete fitness. "

In line with the explanation above, regarding the implementation of SP3OR. 
The Sp3or's Policy Evaluation In Sports For Development And Peace (SDP) Perspective: New Direction For Sports

Development In The Future

Destri Hardiyani, Yudha Munajat Saputra, Amung Ma'mun

destrihard@gmail.com

According to the main informant (SACPI) stated that "the SP3OR's carry out their duties according to directions from the Dispora, the tasks they must undertake include: compiling plans and programs sports coaching and development work in communities in their respective working areas; identify, inventory, foster and develop sports in community, in their respective working areas including sports clubs, associations sports and sports centers, then carry out coaching and sports training at Public, motivate and mobilize people to carry out sports in a manner true and continuous; monitor and evaluate the implementation of sports in Public; Provide explanations to agency agencies and the wider community in general about the importance of exercise. " This is stated in the assignment policy the main and function of SP3OR in Governor Regulation No.7 of 2018.

Rencana Strategis (Renstra) of the Regional Development Planning Agency of West Java Province states that the targets in realizing this development are as follows: (1) Increased integration of development programs/activities; (2) Consistency between program activities that have been implemented and plans that have been prepared previously; and (3) Availability of accountable statistical data (up to date, valid and easy to access for the public) to support planning (Renstra, 2018). In relation to sport development and peace (SDP), of course the SP3OR program has the same vision of the program with SDGs. In this case the researcher uses a logic model to evaluate the SP3OR's policy of the program that has been implemented. The development of sports in the community by SP3OR is based on West Java Governor Regulation (Pergub) No. 7 of 2018, the implementation of these indicators as found by researchers during interviews is said to have been carried out as a whole. However, what is felt is that there is still a lack of equity. This was conveyed by the key informant (YMS) because the ratio between the number of districts and alumni or SP3OR was not balanced. If you imagine the number of districts is 27 , the number of sub-districts is 550 , and the most is the number of villages up to 6000 , this SP3OR program should not only be at the district but must be at the village. With this amount, the government has not been able to finance it. Therefore, currently only 118 have been filled, perhaps the number of sub-districts is not yet ideal. In the future, there must be a policy from the government to increase the budget.

From the perspective of sport development and peace (SDP), the SP3OR program is more directed towards research conducted by Levermore (2008) where there are several points similar and carried out such as empowerment, where the evaluation of the process through a logic model is to formulate a work plan and work program for sports coaching 
The Sp3or's Policy Evaluation In Sports For Development And Peace (SDP) Perspective: New Direction For Sports

Development In The Future

Destri Hardiyani, Yudha Munajat Saputra, Amung Ma'mun

destrihard@gmail.com

and development in the community in their respective work areas and carrying out sports coaching and training in the community. The second point is to raise awareness, stated in the evaluation of the SP3OR's program process, which describes SP3OR with its task to motivate and mobilize people to carry out sports properly and sustainably. Furthermore, the third point is an intercultural understanding, although according to the key informant (YMS) the SP3OR program has not approached the meaning of the word "peace" in terms of sport development and peace, but in evaluating the process the SP3OR program has identified, inventoried, fostered and developed sports in the community, in their respective working areas including sports clubs, sports associations and sports centers.

Closely related to the direction of sports development in the future, when referring to the SKN Law No. 3 of 2005 article 26, it is explained that "Development and development of recreational sports is carried out as an effort to develop workshops and activate sports associations in the community, as well as organize recreational sports festivals that tiered and sustainable at the regional, national and international levels." This is clearly illustrated from the evaluation of the output (the product produced) where the form of products that SP3OR personnel present in the community include monitoring sports activities, implementing Sunday sports programs, sports competition programs in sub-districts, "bela diri budaya" programs, clean Friday and healthy program, traditional sports programs, become a gymnastics instructor, and help distribute social assistance from the government in collaboration with the sub-district and the Ministry of Social Affairs. Thus, the SP3OR's policy evaluation in the perspective of sport development and peace (SDP) is a new direction for sports development in the future, again mapped in evaluation outcome through a logic model, the SP3OR program has 3 benefits which are divided into short-term benefits where people are motivated to do sports. and moved to maintain cleanliness, then in the medium term where exercise habits arise in the community and an increase in the number of community participation in sports, and long-term benefits where through the SP3OR program it is expected that less people visit the hospital, reduce the level of hypokinetic disease (lack of movement), heart disease, diabetes and obesity.

\section{CONCLUSIONS AND SUGGESTIONS}

Based on the results of qualitative research using triangulation, regarding the evaluation of SP3OR policies through the perspective of Sport Development and Peace (SDP) for future sports development. Then several conclusions can be drawn, namely: 
The Sp3or's Policy Evaluation In Sports For Development And Peace (SDP) Perspective: New Direction For Sports

Development In The Future

Destri Hardiyani, Yudha Munajat Saputra, Amung Ma'mun

destrihard@gmail.com

Based on the data obtained by researchers, the idea of forming the SP3OR program was motivated by the low level of "angka partisipasi masyarakat dalam berolahraga" (APMO) in West Java. The selected SP3OR employees, each of whom has met the predetermined criteria, including the applicant must be a sports major or sports graduate, and an age limit of not more than 40 years and not yet bound by a work contract. Furthermore, SP3OR personnel attend training to increase knowledge and skills in order to equip SP3OR staff when they are directly involved in the community. Because after being elected, SP3OR will be the driving force for sports participation in the community. The SP3OR's policy direction is confirmed in West Java Governor's Regulation (Pergub) No. 7 of 2018. All policies regarding SP3OR are contained in it.

In its implementation, SP3OR personnel carry out their duties according to the direction of the Ministry of Youth and Sports, the tasks they must undertake include: compiling work plans and work programs for sports coaching and development in communities in their respective working areas; identify, inventory, foster and develop sports in the community, in their respective working areas including sports clubs, sports associations and sports centers; then carry out coaching and sports training in the community; motivating and mobilizing people to carry out sports properly and continuously; monitor and evaluate the implementation of sports in the community; Provide explanations to organizational agencies and the general public about the importance of sports. This is contained in the policy on the main duties and functions of SP3OR in the Governor's Regulation No.7 of 2018.

The presence of SP3OR personnel for the people of West Java has a positive impact, especially in terms of motivation, moving people to exercise to make sports a necessity for healthy living so that it can improve the quality of life for the community and increase the West Java Community Participation Rate in sports. So that recreational sports carried out by the community with a passion and ability that grow and develop in accordance with the conditions and cultural values of the local community for health, fitness and pleasure. This means that recreational sports are sports based on one's interest in sports. Then, the types of recreational sports also adjust to their respective regions, which are closely related to various kinds of traditional sports, which differ from region to region.

Based on the results of the study, the SP3OR program in increasing APMO in West Java is carried out well. This implies that the policies that run on the SP3OR's program have a very important role in achieving goals, because starting from the policy will 
The Sp3or's Policy Evaluation In Sports For Development And Peace (SDP) Perspective: New Direction For Sports

Development In The Future

Destri Hardiyani, Yudha Munajat Saputra, Amung Ma'mun

destrihard@gmail.com

provide direction for action, and how these actions must be taken in order to achieve the desired goals.

For the Government; Government of West Java Province should increase the number of SP3OR personnel, which were originally scattered in 27 districts and cities in West Java to be scattered to every village. Of course, this is not easy considering there is a budget that must be increased as well.

For the Community; They must have the awareness to keep doing physical activities (exercising) in between their busy lives. And the community builds a positive commitment in carrying out a healthy lifestyle.

For Further Researchers; There is no finished word for learning and creating new things, thus for future researchers it is suggested to examine more deeply about the evaluation of SP3OR's policies from the SDP perspective for the direction of sports development in the future. The novelty of research will further enrich the knowledge they have, especially regarding SP3OR from the perspective of SDP, the more the issue is raised, the more research opportunities will be created.

\section{REFERENCES}

Bappeda. (2020). Rancangan Rencana Kerja Pemerintah Daerah Provinsi Jawa Barat Tahun 2021.

Dispora Jawabarat. (2020). Buku Pedoman Kerja Tenaga SP3OR Jawa Barat tahun 2020- 2022.

Heryana, A. (2018). Informan dan Pemilihan Informan dalam Penelitian Kualitatif. Jurnal Kualitatif, December, 1-15.

Huffman, A. M. (2011). Using Sport to Build Community : Service- Learning with Iraqi Refugees. http://trace.tennessee.edu/utk_graddiss/1085

Levermore, R. (2008). Sport in international development. Routledge Handbook of Sports Development, 14(2), 55-66. https://doi.org/10.4324/9780203885581.ch21

Ma'mun, A. (2015). Kepemimpinan dan Kebijakan Pembangunan Olahraga. In Universitas Pendidikan Indonesia.

Rahadian, A. (2020). Kebijakan Olahraga dalam Pemerintahan Lokal: Sebuah Penelitian dalam Merumuskan Rancangan Induk Pembangunan Olahraga Nasional. June.

Ramadhan, G. (2020). Implementasi Undang-Undang Sistem Keolahragaan Nasional dalam Pengembangan Olahraga di Jawa Barat. 
The Sp3or's Policy Evaluation In Sports For Development And Peace (SDP) Perspective: New Direction For Sports Development In The Future

Destri Hardiyani, Yudha Munajat Saputra, Amung Ma'mun

destrihard@gmail.com

Renstra. (2018). Rencana strategis.

RPJMD. (2018). RPJMD Provinsi Jabar 2018 - 2023.

RPJPD Jawa Barat. (2010). Rencana Pembangunan Jangka Panjang Daerah Provinsi Jawa Barat Tahun 2005-2025. 